\title{
Study of sensitivity to curare in certain neurological disorders using a regional technique
}

\author{
J. COLIN BROWN ${ }^{1}$ AND J. EDMOND CHARLTON
}

\author{
From the Departments of Anaesthesia and Neurology, Royal Victoria Infirmary, \\ Newcastle upon Tyne
}

SYNOPSIS A regional technique for the study of curare sensitivity has been applied to patients with Duchenne type muscular dystrophy, myotonic disorders, certain lower motor neurone disorders, to patients with weakness in the arm after hemiplegia, to patients with hyper-reflexia and hypertonia without weakness, and to Parkinsonism. In the dystrophy patients, sensitivity to curare differs from normal controls in that the neuromuscular block persists. The possibilities that this latent defect of neuromuscular transmission is the result of acetylcholine deficiency due to a prejunctional defect or the result of alterations in the property of the postjunctional membrane are discussed. In the myotonic and lower motor neurone disorders, curare sensitivity was similar to that of normal controls. After hemiplegia, the affected side shows resistance to curare when compared with the unaffected side. In states of hyper-reflexia and hypertonia, however, the sensitivity to curare is greater than in normal controls. In Parkinsonism, sensitivity is similar to that of the controls. The results in uppern motor neurone lesions are discussed in relation to the dependence of neuromuscular transmission upon the motor neurone, which, in turn, is dependent upon descending impulses.

From time to time, the possibility of defective neuromuscular transmission is raised in patients with primary disorders of nerve or muscle. There are reports of myasthenic defects in patients with amyotrophic lateral sclerosis (Mulder et al., 1959), in peripheral neuropathy (Baginsky, 1968), in myopathies (Ricker and Mertens, 1968; Simpson, 1974), and in myotonia (IschTreussard et al., 1968). Furthermore, undue sensitivity to curare has been noted on occasion in other than myasthenic disorders (Ross, 1963; Oosterhuis and de Haas, 1969; Mathew et al., 1970). Disorders which impair the structure and function of the nerve and muscle fibre might be expected to damage the adjacent neuromuscular junction. The functional reserve of this junction is such that latent alterations may not be revealed by physiological studies. Thus, widespread subclinical alterations in neuromuscular function may pass unobserved in such disorders. As undue curare sensitivity may indicate latent defects of neuromuscular transmission, a regional

1 Present address: Norfolk and Norwich Hospital, Norwich, Norfolk, NR1 3SR. technique has been applied to the study certain myopathies and neuropathies.

Since transynaptic degeneration may result in changes in the lower motor neurone (Young, 1966), and in hemiplegia (McComas et al., 1973) and Parkinsonism (Sica et al., 1973) there is a reduction in the total number of functioning motor units, some alteration in the function of the surviving units might reasonably be expected in these conditions also. These central nervous system disorders could be reflected in changes in neuromuscular transmission: indeed, structural abnormalities in the motor end plate have been shown in Parkinsonism (Tuncbay and Boshes, 1966). For this reason, the regional technique for the study of curare sensitivity has also been applied to patients with upper motor neurone disorders and Parkinsonism.

\section{METHODS}

Eleven patients with advanced Duchenne type muscular dystrophy, eight patients with dystrophia myotonica, four patients with myotonia congenita, 
TABLE 1

DUCHENNE MUSCULAR DYSTROPHY (MUSCLE ACTION POTENTIAL EXPRESSED AS \% OF PRE-CURARE AMPLITUDE)

\begin{tabular}{|c|c|c|c|c|c|c|c|c|c|c|c|c|c|}
\hline \multirow[t]{3}{*}{ Patient } & \multirow{3}{*}{$\begin{array}{l}\text { Age } \\
\text { (yr) }\end{array}$} & \multirow{3}{*}{$\begin{array}{c}\text { Degree } \\
\text { of } \\
\text { weakness } \\
(0-+++)\end{array}$} & \multirow{3}{*}{$\begin{array}{c}\text { Ampli- } \\
\text { tude } \\
\text { of } \\
\text { evoked } \\
\text { MAP } \\
(m V)\end{array}$} & \multirow{3}{*}{$\begin{array}{c}\text { Dosage } \\
\text { of } \\
\text { curare } \\
\text { (mg) }\end{array}$} & \multicolumn{9}{|c|}{ Response to stimulus train at } \\
\hline & & & & & \multicolumn{3}{|c|}{1 minute } & \multicolumn{3}{|c|}{11 minutes } & \multicolumn{3}{|c|}{21 minutes } \\
\hline & & & & & $\begin{array}{c}\text { First } \\
\text { re- } \\
\text { sponse }\end{array}$ & $\begin{array}{c}\text { Last } \\
\text { re- } \\
\text { sponse }\end{array}$ & $\begin{array}{c}\text { Fade } \\
\text { ratio }\end{array}$ & $\begin{array}{c}\text { First } \\
\text { re- } \\
\text { sponse }\end{array}$ & $\begin{array}{c}\text { Last } \\
\text { re- } \\
\text { sponse }\end{array}$ & $\begin{array}{l}\text { Fade } \\
\text { ratio }\end{array}$ & $\begin{array}{c}\text { First } \\
\text { re- } \\
\text { sponse }\end{array}$ & $\begin{array}{c}\text { Last } \\
\text { re- } \\
\text { sponse }\end{array}$ & $\begin{array}{l}\text { Fade } \\
\text { ratio }\end{array}$ \\
\hline $\begin{array}{l}\text { D.B. } \\
\text { M.McC. } \\
\text { D.S. } \\
\text { B.R. } \\
\text { J.L. } \\
\text { P.J. } \\
\text { D.W. } \\
\text { A.B. } \\
\text { N.M. } \\
\text { B.S. } \\
\text { B.P. }\end{array}$ & $\begin{array}{l}13 \\
15 \\
14 \\
14 \\
15 \\
17 \\
22 \\
16 \\
24 \\
28 \\
14\end{array}$ & $\begin{array}{c}++ \\
++ \\
++ \\
+++ \\
++ \\
++ \\
+ \\
++ \\
+ \\
++ \\
+\end{array}$ & $\begin{array}{r}1 \cdot 8 \\
6.3 \\
1 \cdot 3 \\
0.7 \\
3 \cdot 4 \\
8 \cdot 0 \\
9 \cdot 6 \\
2.9 \\
8 \cdot 1 \\
4 \cdot 3 \\
12 \cdot 8\end{array}$ & $\begin{array}{l}0.25 \\
0.25 \\
0.5 \\
0.5 \\
0.25 \\
0.25 \\
0.5 \\
0.5 \\
0.5 \\
0.5 \\
0.25\end{array}$ & $\begin{array}{l}72 \\
85 \\
78 \\
70 \\
74 \\
64 \\
54 \\
48 \\
32 \\
28 \\
40\end{array}$ & $\begin{array}{l}52 \\
80 \\
68 \\
38 \\
48 \\
48 \\
36 \\
32 \\
16 \\
10 \\
22\end{array}$ & $\begin{array}{l}1 \cdot 38 \\
1 \cdot 06 \\
1 \cdot 14 \\
1 \cdot 85 \\
1 \cdot 54 \\
1 \cdot 34 \\
1 \cdot 5 \\
1 \cdot 5 \\
2 \cdot 0 \\
2 \cdot 8 \\
1 \cdot 82\end{array}$ & $\begin{array}{l}78 \\
74 \\
78 \\
60 \\
62 \\
56 \\
56 \\
56 \\
34 \\
26 \\
30\end{array}$ & $\begin{array}{l}60 \\
70 \\
70 \\
34 \\
48 \\
40 \\
36 \\
32 \\
14 \\
12 \\
14\end{array}$ & $\begin{array}{l}1 \cdot 3 \\
1 \cdot 06 \\
1 \cdot 11 \\
1 \cdot 76 \\
1 \cdot 3 \\
1 \cdot 4 \\
1 \cdot 52 \\
1 \cdot 75 \\
2 \cdot 43 \\
2 \cdot 16 \\
2 \cdot 15\end{array}$ & $\begin{array}{l}84 \\
70 \\
60 \\
74 \\
70 \\
58 \\
58 \\
64 \\
40 \\
34 \\
42\end{array}$ & $\begin{array}{l}74 \\
70 \\
60 \\
50 \\
52 \\
44 \\
40 \\
42 \\
18 \\
12 \\
22\end{array}$ & $\begin{array}{l}1 \cdot 14 \\
1 \cdot 00 \\
1 \cdot 00 \\
1 \cdot 48 \\
1 \cdot 34 \\
1 \cdot 34 \\
1 \cdot 46 \\
1 \cdot 52 \\
2 \cdot 2 \\
2 \cdot 8 \\
1.9\end{array}$ \\
\hline \multicolumn{5}{|c|}{$\begin{array}{l}\text { Mean } \\
\text { Standard deviation } \\
\text { Mean (normals) } \\
t \text { test (to normals) } \\
\mathbf{P}\end{array}$} & $\begin{array}{l}58 \cdot 6 \\
19 \cdot 4 \\
61 \cdot 8 \\
0 \cdot 398 \\
>0 \cdot 1\end{array}$ & $\begin{array}{c}40.9 \\
21 \cdot 3 \\
43 \cdot 4 \\
0.291 \\
>0.1\end{array}$ & $\begin{array}{l}1.63 \\
0.46 \\
1.76 \\
0.529 \\
>0.1\end{array}$ & $\begin{array}{l}55 \cdot 5 \\
18.4 \\
82.6 \\
4.093 \\
<0.001\end{array}$ & $\begin{array}{l}39 \cdot 1 \\
21 \cdot 2 \\
70 \cdot 1 \\
3.595 \\
<0.002\end{array}$ & $\begin{array}{r}1.63 \\
0.46 \\
1.29 \\
2.36 \\
<0.05\end{array}$ & $\begin{array}{l}59 \cdot 5 \\
15 \cdot 5 \\
89 \cdot 4 \\
5.685 \\
<0.001\end{array}$ & $\begin{array}{c}44 \cdot 0 \\
20 \cdot 3 \\
84 \cdot 3 \\
5 \cdot 52 \\
<0.001\end{array}$ & $\begin{array}{l}1.56 \\
0.55 \\
1.09 \\
3.507 \\
<0.002\end{array}$ \\
\hline
\end{tabular}

TABLE 2

MYOTONIC DISORDERS (MUSCLE ACTION POTENTIAL EXPRESSED AS \% OF PRE-CURARE AMPLITUDE)

\begin{tabular}{|c|c|c|c|c|c|c|c|c|c|c|c|c|c|c|}
\hline \multirow[t]{3}{*}{ Patient } & \multirow{3}{*}{$\begin{array}{l}\text { Age } \\
(y r)\end{array}$} & \multirow{3}{*}{$\begin{array}{c}\text { Degree } \\
\text { of } \\
\text { weak- } \\
\text { ness }\end{array}$} & \multirow{3}{*}{$\begin{array}{c}\text { Degree } \\
\text { of } \\
\text { myo- } \\
\text { tonia }\end{array}$} & \multirow{3}{*}{$\begin{array}{c}\text { MAP } \\
\text { ampli- } \\
\text { tude } \\
(m V)\end{array}$} & \multirow{3}{*}{$\begin{array}{c}\text { Dosage } \\
\text { of } \\
\text { curare } \\
\text { (mg) }\end{array}$} & \multicolumn{9}{|c|}{ Response to stimulus trains at } \\
\hline & & & & & & \multicolumn{3}{|c|}{1 minute } & \multicolumn{3}{|c|}{11 minutes } & \multicolumn{3}{|c|}{21 minutes } \\
\hline & & & & & & $\begin{array}{c}\text { First } \\
\text { re- } \\
\text { sponse }\end{array}$ & $\begin{array}{c}\text { Last } \\
\text { re- } \\
\text { sponse }\end{array}$ & $\begin{array}{l}\text { Fade } \\
\text { ratio }\end{array}$ & $\begin{array}{c}\text { First } \\
\text { re- } \\
\text { sponse }\end{array}$ & $\begin{array}{c}\text { Last } \\
\text { re- } \\
\text { sponse }\end{array}$ & $\begin{array}{l}\text { Fade } \\
\text { ratio }\end{array}$ & $\begin{array}{c}\text { First } \\
\text { re- } \\
\text { sponse }\end{array}$ & $\begin{array}{c}\text { Last } \\
\text { re- } \\
\text { sponse }\end{array}$ & $\begin{array}{l}\text { Fade } \\
\text { ratio }\end{array}$ \\
\hline \multicolumn{15}{|c|}{ Dystrophia myotonica } \\
\hline $\begin{array}{l}\text { C.P. } \\
\text { E.T. } \\
\text { H.L. } \\
\text { J.B. } \\
\text { S.J. } \\
\text { E.K. } \\
\text { L.C. } \\
\text { A.C. }\end{array}$ & $\begin{array}{l}55 \\
45 \\
44 \\
50 \\
40 \\
46 \\
42 \\
57\end{array}$ & $\begin{array}{c}+ \\
+ \\
- \\
+ \\
+++ \\
++ \\
- \\
+++\end{array}$ & $\begin{array}{c}+++ \\
++ \\
++ \\
++ \\
+++ \\
++ \\
+ \\
+\end{array}$ & $\begin{array}{r}14 \cdot 0 \\
6 \cdot 9 \\
4 \cdot 6 \\
12 \cdot 1 \\
10 \cdot 2 \\
13 \cdot 5 \\
9 \cdot 7 \\
5 \cdot 6\end{array}$ & $\begin{array}{l}0.25 \\
0.5 \\
0.5 \\
0.5 \\
0.5 \\
0.5 \\
0.5 \\
0.5\end{array}$ & $\begin{array}{r}104 \\
84 \\
84 \\
64 \\
50 \\
54 \\
62 \\
64\end{array}$ & $\begin{array}{r}100 \\
80 \\
44 \\
46 \\
22 \\
28 \\
28 \\
46\end{array}$ & $\begin{array}{l}1 \cdot 00 \\
1 \cdot 04 \\
1 \cdot 9 \\
1 \cdot 38 \\
2 \cdot 28 \\
1 \cdot 92 \\
2.2 \\
1 \cdot 4\end{array}$ & $\begin{array}{r}100 \\
74 \\
100 \\
80 \\
86 \\
72 \\
82 \\
62\end{array}$ & $\begin{array}{r}100 \\
74 \\
100 \\
70 \\
64 \\
48 \\
40 \\
46\end{array}$ & $\begin{array}{l}1.00 \\
1.00 \\
1.00 \\
1 \cdot 14 \\
1 \cdot 34 \\
1 \cdot 5 \\
2 \cdot 05 \\
1.35\end{array}$ & $\begin{array}{r}100 \\
66 \\
100 \\
84 \\
88 \\
78 \\
86 \\
76\end{array}$ & $\begin{array}{r}100 \\
66 \\
100 \\
78 \\
86 \\
64 \\
60 \\
54\end{array}$ & $\begin{array}{l}1.00 \\
1.00 \\
1.00 \\
1.08 \\
1.02 \\
1.22 \\
1.44 \\
1.41\end{array}$ \\
\hline \multicolumn{6}{|c|}{$\begin{array}{l}\text { Mean } \\
\text { Standard deviation } \\
\text { Mean (normals) } \\
t \text { test (to normals) } \\
P>0.1\end{array}$} & $\begin{array}{c}70 \cdot 3 \\
19 \cdot 5 \\
61 \cdot 8 \\
0 \cdot 15\end{array}$ & $\begin{array}{c}49 \cdot 3 \\
16 \cdot 4 \\
43 \cdot 4 \\
0 \cdot 59\end{array}$ & $\begin{array}{l}1 \cdot 64 \\
0.61 \\
1 \cdot 76 \\
0.14\end{array}$ & $\begin{array}{c}82.0 \\
25 \cdot 7 \\
82.6 \\
0.62\end{array}$ & $\begin{array}{c}67 \cdot 8 \\
31 \cdot 8 \\
70 \cdot 1 \\
0 \cdot 19\end{array}$ & $\begin{array}{l}1.29 \\
0.43 \\
1.29 \\
0.34\end{array}$ & \begin{tabular}{|c|}
$84 \cdot 8$ \\
$17 \cdot 8$ \\
$89 \cdot 4$ \\
$1 \cdot 05$
\end{tabular} & $\begin{array}{c}76 \cdot 0 \\
27 \cdot 0 \\
84 \cdot 3 \\
0.45\end{array}$ & $\begin{array}{l}1 \cdot 15 \\
0.28 \\
1.09 \\
0.37\end{array}$ \\
\hline \multicolumn{15}{|c|}{ Myotonia congenita } \\
\hline $\begin{array}{l}\text { M.H. } \\
\text { D.R. } \\
\text { G.H. } \\
\text { E.A. }\end{array}$ & $\begin{array}{l}38 \\
20 \\
44 \\
36\end{array}$ & $\begin{array}{l}- \\
- \\
-\end{array}$ & $\begin{array}{c}+ \\
++ \\
+ \\
+\end{array}$ & $\begin{array}{l}15 \cdot 8 \\
14 \cdot 0 \\
20 \cdot 6 \\
18 \cdot 1\end{array}$ & $\begin{array}{l}0.5 \\
0.5 \\
0.5 \\
0.5\end{array}$ & $\begin{array}{l}70 \\
76 \\
62 \\
32\end{array}$ & $\begin{array}{l}26 \\
54 \\
44 \\
18\end{array}$ & $\begin{array}{l}2 \cdot 7 \\
1 \cdot 4 \\
1 \cdot 4 \\
1 \cdot 77\end{array}$ & $\begin{array}{r}124 \\
86 \\
84 \\
62\end{array}$ & $\begin{array}{r}108 \\
80 \\
72 \\
31\end{array}$ & $\begin{array}{l}1 \cdot 17 \\
1 \cdot 08 \\
1 \cdot 17 \\
2\end{array}$ & $\begin{array}{r}124 \\
90 \\
86 \\
90\end{array}$ & $\begin{array}{r}124 \\
90 \\
86 \\
58\end{array}$ & $\begin{array}{l}1.00 \\
1.00 \\
1.00 \\
1.55\end{array}$ \\
\hline \multicolumn{6}{|c|}{$\begin{array}{l}\text { Mean } \\
\text { Standard deviation }\end{array}$} & $\begin{array}{l}60 \cdot 6 \\
19 \cdot 5\end{array}$ & $\begin{array}{l}35 \cdot 5 \\
16 \cdot 4\end{array}$ & $\begin{array}{l}1 \cdot 88 \\
0.61\end{array}$ & $\begin{array}{l}89 \cdot 0 \\
25 \cdot 7\end{array}$ & $\begin{array}{l}72 \cdot 8 \\
31 \cdot 8\end{array}$ & $\begin{array}{l}1 \cdot 36 \\
0 \cdot 43\end{array}$ & $\begin{array}{l}97 \cdot 5 \\
17 \cdot 8\end{array}$ & $\begin{array}{l}89 \cdot 5 \\
27 \cdot 0\end{array}$ & $\begin{array}{l}1 \cdot 14 \\
0 \cdot 28\end{array}$ \\
\hline
\end{tabular}


and nine patients with weakness of the hands due to different types of lower motor neurone disorder were studied. In 12 patients with hemiplegia due to a cerebrovascular accident, the study was performed in each arm on different days. In each case, there had been loss of strength in the arm at the time of the stroke and, when studied, there was still some weakness. Eight patients were then studied who had upper motor neurone signs in the arms without weakness. Each had a spastic paraplegia with, in addition, increased tone and excessively brisk reflexes in the arms. Finally, eight patients with Parkinsonism were studied.
Before each study, the degree of weakness in the hand and, where relevant, the wasting, muscle tone, tendon reflexes, and the degree of myotonia or of dyskinesia were assessed and graded from 0 (no abnormality) to +++ (highly abnormal). The relevant clinical details are summarized in the Tables.

The technique for studying curare sensitivity has been described in a previous paper (Brown et al., 1975 ) in which the tourniquet was applied to the forearm to occlude the circulation to $720 \mathrm{ml}$ of the hand and forearm and $0.5 \mathrm{mg}$ d-tubocurarine given in $20 \mathrm{ml}$ saline. So that the tourniquet would be at

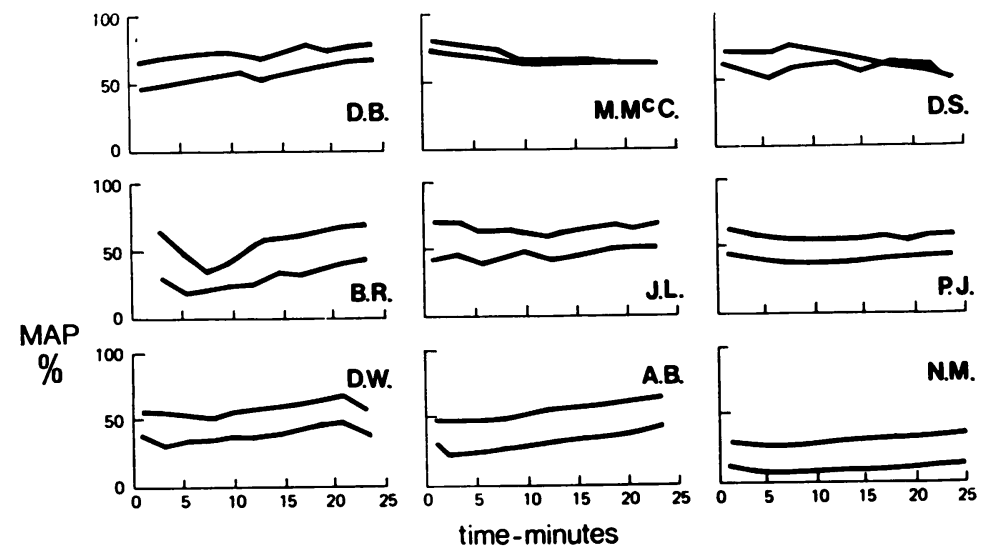

FIG. 1. Effect of 'regional' injection of d-tubocurarine in Duchenne muscular dystrophy (see text).
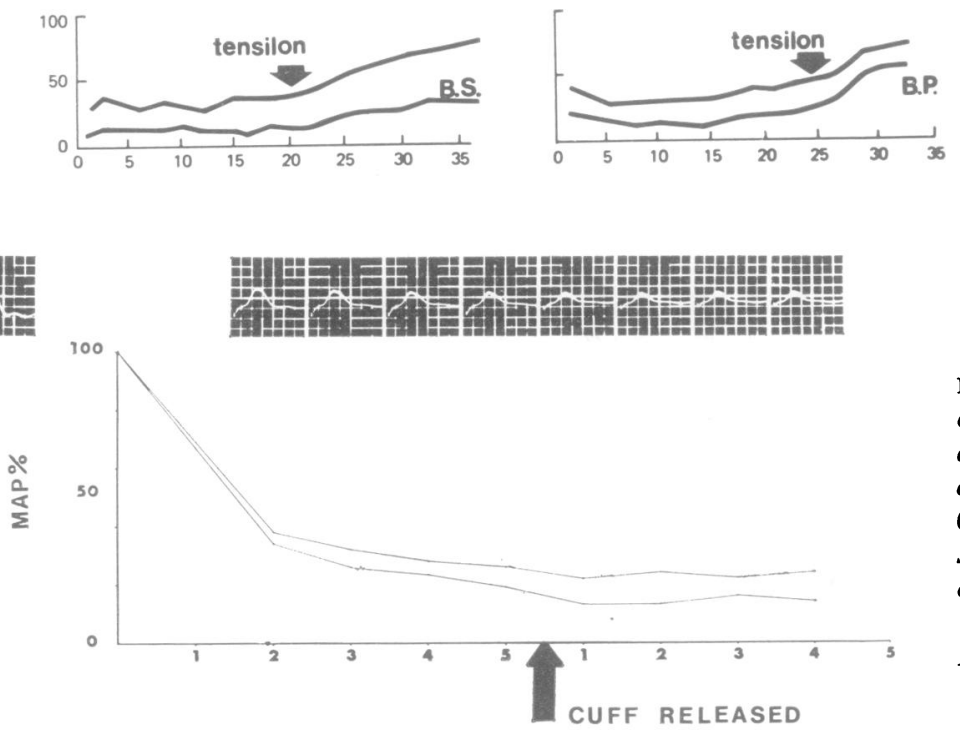

FIG. 2. Speed of response to curare in patient A.B. MAP amplitude plotted during and after ischaemia after injection of $0.5 \mathrm{mg}$ d-tubocurarine. Insets: superimposed MAP responses evoked by the stimulus trains. Vertical divisions, $0.5 \mathrm{mV}$. Horizontal divisions, $2 \mathrm{~ms}$. 
TABLE 3

DENERVATION (MUSCLE ACTION POTENTIAL EXPRESSED AS \% OF PRE-CURARE AMPLITUDE)

\begin{tabular}{|c|c|c|c|c|c|c|c|c|c|c|c|c|}
\hline \multirow[t]{3}{*}{ Patient } & \multirow{3}{*}{$\begin{array}{l}\text { Age } \\
(y r)\end{array}$} & \multirow[t]{3}{*}{ Diagnosis } & \multirow{3}{*}{$\begin{array}{c}\text { Degree } \\
\text { of } \\
\text { weak- } \\
\text { ness }\end{array}$} & \multicolumn{9}{|c|}{ Response to stimulus trains at } \\
\hline & & & & \multicolumn{3}{|c|}{1 minute } & \multicolumn{3}{|c|}{11 minutes } & \multicolumn{3}{|c|}{21 minutes } \\
\hline & & & & $\begin{array}{c}\text { First } \\
\text { re- } \\
\text { sponse }\end{array}$ & $\begin{array}{c}\text { Last } \\
\text { re- } \\
\text { sponse }\end{array}$ & $\begin{array}{l}\text { Fade } \\
\text { ratio }\end{array}$ & $\begin{array}{c}\text { First } \\
\text { re- } \\
\text { sponse }\end{array}$ & $\begin{array}{c}\text { Last } \\
\text { re- } \\
\text { sponse }\end{array}$ & $\begin{array}{l}\text { Fade } \\
\text { ratio }\end{array}$ & $\begin{array}{c}\text { First } \\
\text { re- } \\
\text { sponse }\end{array}$ & $\begin{array}{c}\text { Last } \\
\text { re- } \\
\text { sponse }\end{array}$ & $\begin{array}{l}\text { Fade } \\
\text { ratio }\end{array}$ \\
\hline T.S. & 68 & $\begin{array}{l}\text { Progressive muscular } \\
\text { atrophy }\end{array}$ & ++ & 92 & 84 & $1 \cdot 1$ & 104 & 100 & $1 \cdot 04$ & 112 & 112 & $1 \cdot 00$ \\
\hline J.T. & 51 & Radiculopathy & ++ & 86 & 52 & 1.66 & 94 & 83 & $1 \cdot 13$ & 100 & 96 & $1 \cdot 04$ \\
\hline J.M. & 16 & Peripheral neuropathy & + & 66 & 42 & $1 \cdot 57$ & 92 & 82 & $1 \cdot 12$ & 110 & 106 & 1.04 \\
\hline H.A. & 55 & $\begin{array}{l}\text { Progressive muscular } \\
\text { atrophy }\end{array}$ & ++ & 62 & 48 & $1 \cdot 3$ & 94 & 78 & $1 \cdot 2$ & 100 & 100 & $1 \cdot 00$ \\
\hline C.D. & 56 & Ulnar nerve palsy & ++ & 72 & 56 & $1 \cdot 28$ & 90 & 80 & $1 \cdot 12$ & 98 & 94 & 1.04 \\
\hline W.B. & 59 & Radiculopathy & ++ & 44 & 26 & $1 \cdot 7$ & 64 & 46 & $1 \cdot 38$ & 72 & 60 & $1 \cdot 2$ \\
\hline J.R. & 38 & $\begin{array}{l}\text { Progressive muscular } \\
\text { atrophy }\end{array}$ & $+t+$ & 44 & 30 & $1 \cdot 46$ & 62 & 46 & $1 \cdot 35$ & 62 & 46 & $1 \cdot 35$ \\
\hline C.D. & 56 & Ulnar nerve palsy & + & 30 & 19 & $1 \cdot 58$ & 44 & 32 & $1 \cdot 37$ & 60 & 42 & 1.42 \\
\hline J.W. & 62 & $\begin{array}{l}\text { Progressive muscular } \\
\text { atrophy }\end{array}$ & ++ & 26 & 16 & $1 \cdot 62$ & 45 & 22 & $2 \cdot 05$ & 58 & 38 & 1.53 \\
\hline \multirow{4}{*}{\multicolumn{3}{|c|}{$\begin{array}{l}\text { Mean } \\
\text { Standard deviation } \\
\text { Mean (normals) } \\
t \text { test (against normals) } \\
P>0.1\end{array}$}} & & 58.0 & $41 \cdot 4$ & $1 \cdot 47$ & $76 \cdot 5$ & $63 \cdot 2$ & $1 \cdot 31$ & $85 \cdot 8$ & $77 \cdot 1$ & 118 \\
\hline & & & & $23 \cdot 5$ & $21 \cdot 5$ & 0.20 & 22.9 & $27 \cdot 1$ & 0.31 & $22 \cdot 4$ & $30 \cdot 1$ & 0.20 \\
\hline & & & & $61 \cdot 8$ & $43 \cdot 4$ & $1 \cdot 76$ & $82 \cdot 6$ & $70 \cdot 1$ & $1 \cdot 29$ & $89 \cdot 4$ & $84 \cdot 3$ & 1.09 \\
\hline & & & & 0.42 & 0.21 & $1 \cdot 13$ & 0.79 & 0.69 & $0 \cdot 14$ & 0.55 & 0.80 & 1.04 \\
\hline
\end{tabular}

Dystrophia Myotonica

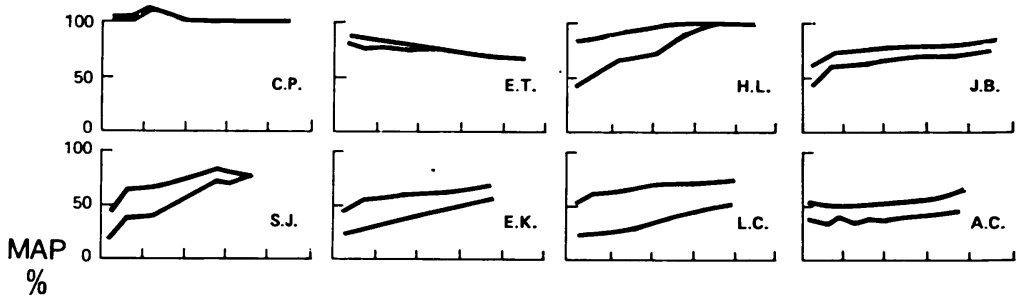

FIG. 3. Effect of 'regional' injection of d-tubocurarine in myotonic disorders (see

Myotonia Congenita text).

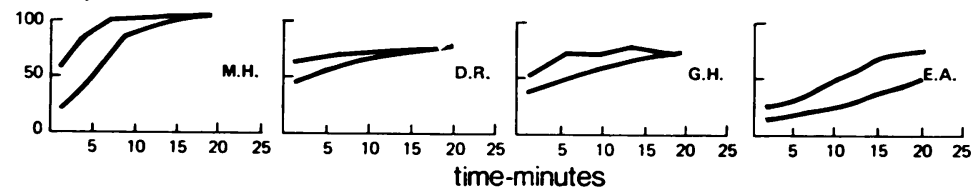

an anatomical site comparable with the 22 subjects who acted as normal controls, it was applied to occlude $360 \mathrm{ml}$ of hand and forearm in those subjects whose hands were particularly small or wasted. In such cases, $0.25 \mathrm{mg}$ d-tubocurarine was then given in $10 \mathrm{ml}$ saline. Table 1 shows that this was necessary in five of the patients with muscular dystrophy and one patient with dystrophia myotonica.
In one patient with muscular dystrophy and one with a hemiplegia $400 \mu \mathrm{Ci}$ of $113 \mathrm{mIn}$ Transferrin in $20 \mathrm{ml}$ saline was injected with the circulation occluded under the same conditions as those described in the study of normal subjects. In each case, rectilinear scanning of the hand at three minutes showed a diffuse uptake comparable with that of a normal subject. 


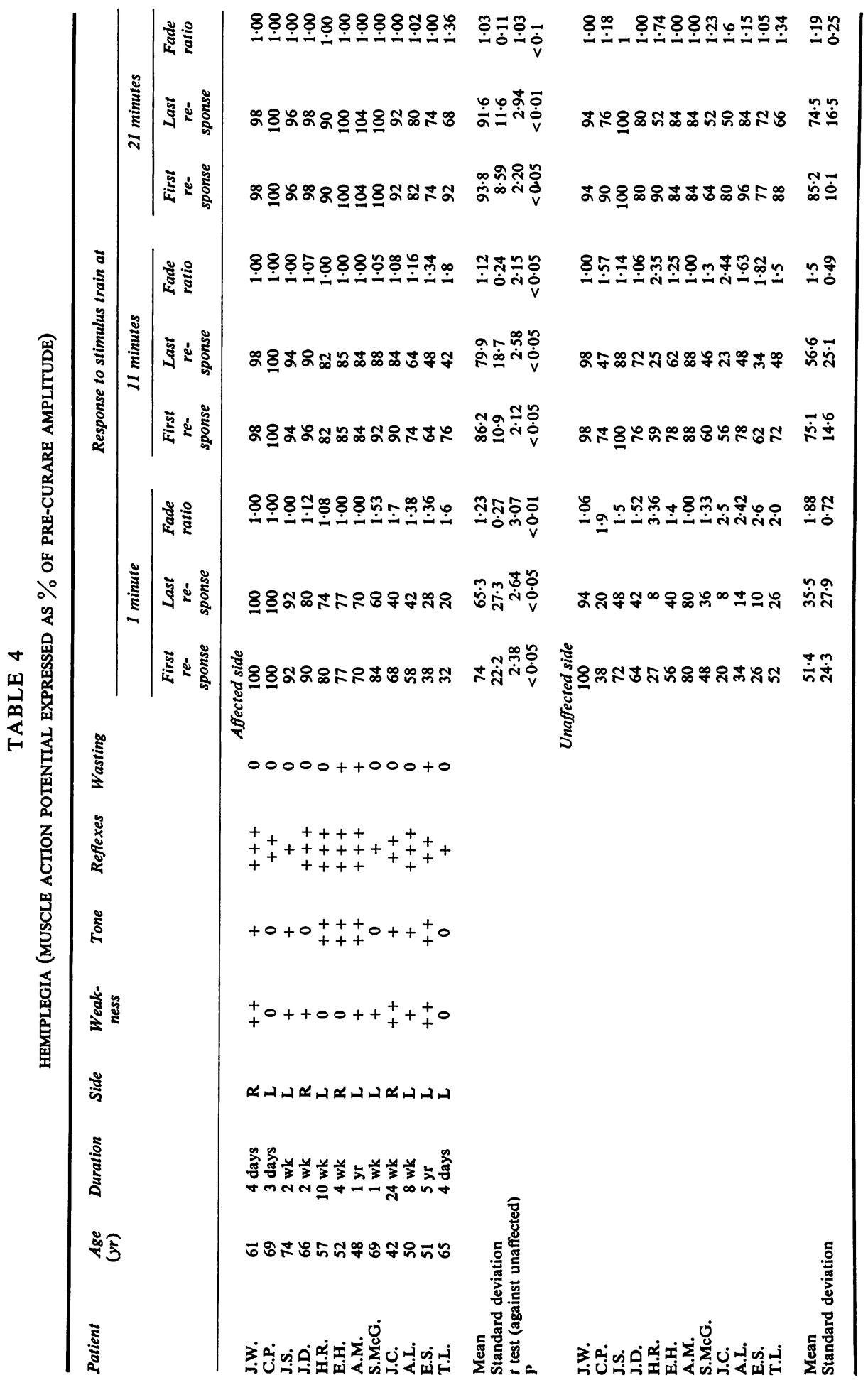



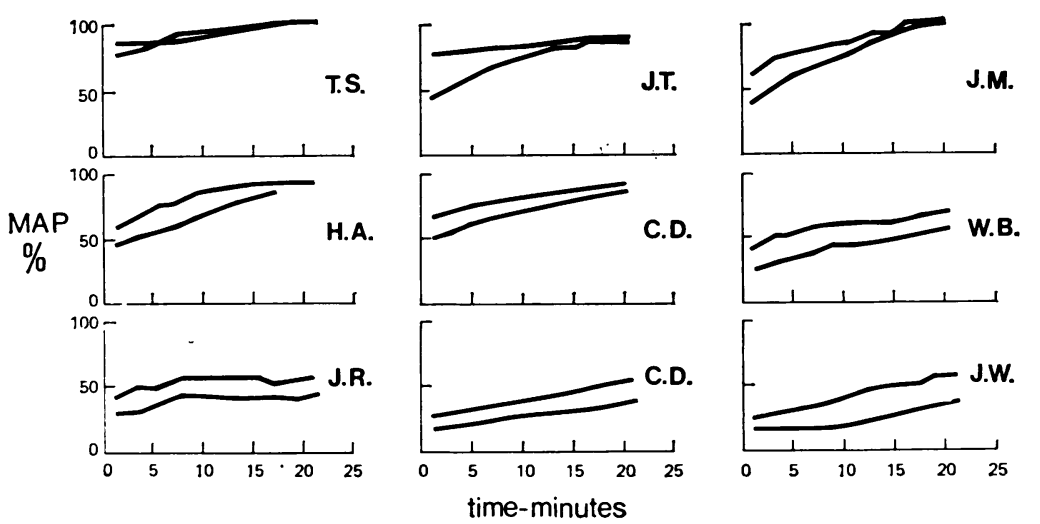

FIG. 4. Effect of 'regional' injection of $0.5 \mathrm{mg}$ of d-tubocurarine in disorders of the lower motor neurone (see text).
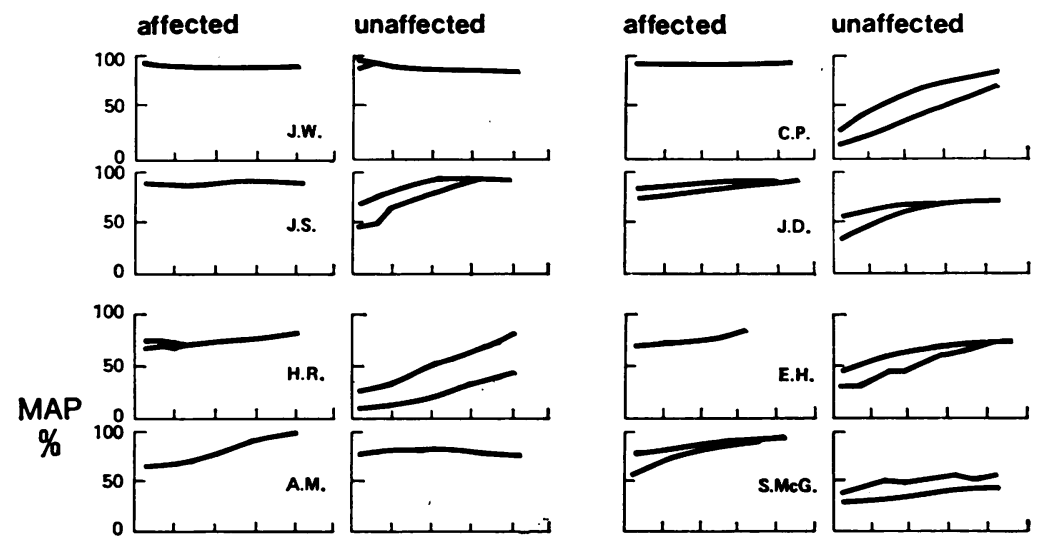

FIG. 5. Effect of 'regional' injection of $0.5 \mathrm{mg}$ of d-tubocurarine in hemiplegia (see text).
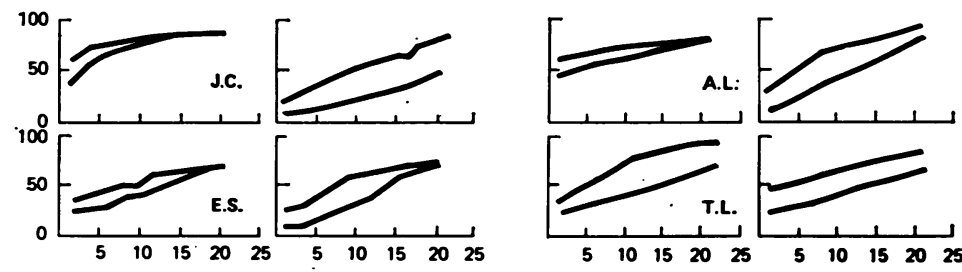

time-minutes

\section{RESULTS}

There is a difference in the response to curare in the muscular dystrophy patients as compared with normal subjects. Figure 1 shows that, though the initial depression of the evoked muscular action potential (MAP) one minute after the ischaemia is comparable with normal subjects, it tends to remain depressed and the subsequent recovery seen in normal subjects fails to occur. This was evident in both subjects with wasted hands in whom the volume of limb occluded was $360 \mathrm{ml}$ and those with hands of normal size where the volume occluded was $720 \mathrm{ml}$. In Table 1 this impression is confirmed: there is no significant difference between the responses in dystrophy and normal subjects at one minute $(P>0 \cdot 1)$ but at 11 and 21 minutes, the mean amplitude of both the first and last responses to each train of stimuli and the 'fade' during the train are significantly different $(\mathrm{P}<0.001)$. While in normal subjects recovery is 
TABLE 5

STATES OF ASYMPTOMATIC HYPER-REFLEXIA IN UPPER LIMBS (MILD SPASTICITY)

(MUSCLE ACTION POTENTIAL EXPRESSED AS \% OF PRE-CURARE AMPLITUDE)

\begin{tabular}{|c|c|c|c|c|c|c|c|c|c|c|}
\hline \multirow[t]{3}{*}{ Patient } & \multirow{3}{*}{$\begin{array}{l}\text { Age } \\
(y r)\end{array}$} & \multicolumn{9}{|c|}{ Response to stimulus train at } \\
\hline & & \multicolumn{3}{|c|}{1 minute } & \multicolumn{3}{|c|}{11 minutes } & \multicolumn{3}{|c|}{21 minutes } \\
\hline & & $\begin{array}{c}\text { First } \\
\text { response }\end{array}$ & $\begin{array}{l}\text { Last } \\
\text { response }\end{array}$ & $\begin{array}{l}\text { Fade } \\
\text { ratio }\end{array}$ & $\begin{array}{c}\text { First } \\
\text { response }\end{array}$ & $\begin{array}{c}\text { Last } \\
\text { response }\end{array}$ & $\begin{array}{l}\text { Fade } \\
\text { ratio }\end{array}$ & $\begin{array}{l}\text { First } \\
\text { response }\end{array}$ & $\begin{array}{c}\text { Last } \\
\text { response }\end{array}$ & $\begin{array}{l}\text { Fade } \\
\text { ratio }\end{array}$ \\
\hline $\begin{array}{l}\text { P.F. (L) } \\
\text { J.F. (R) } \\
\text { P.S. } \\
\text { L.G. } \\
\text { B.S. } \\
\text { J.F. (L) } \\
\text { P.R. } \\
\text { J.S. } \\
\text { P.F. (R) } \\
\text { L.A. }\end{array}$ & $\begin{array}{l}57 \\
41 \\
55 \\
41 \\
57 \\
41 \\
44 \\
58 \\
57 \\
43\end{array}$ & $\begin{array}{l}40 \\
40 \\
40 \\
33 \\
20 \\
20 \\
12 \\
20 \\
12 \\
10\end{array}$ & $\begin{array}{r}14 \\
22 \\
16 \\
20 \\
12 \\
10 \\
4 \\
16 \\
6 \\
6\end{array}$ & $\begin{array}{l}2.85 \\
1.83 \\
2.5 \\
1.65 \\
1.67 \\
2.0 \\
3.0 \\
1.25 \\
2.0 \\
1.66\end{array}$ & $\begin{array}{l}80 \\
74 \\
78 \\
47 \\
68 \\
64 \\
58 \\
43 \\
32 \\
20\end{array}$ & $\begin{array}{r}64 \\
52 \\
50 \\
27 \\
35 \\
32 \\
22 \\
24 \\
15 \\
8\end{array}$ & $\begin{array}{l}1 \cdot 25 \\
1.42 \\
1 \cdot 56 \\
1 \cdot 73 \\
1.93 \\
2.0 \\
2.65 \\
1 \cdot 79 \\
2 \cdot 13 \\
2.5\end{array}$ & $\begin{array}{l}94 \\
86 \\
92 \\
59 \\
88 \\
76 \\
92 \\
68 \\
57 \\
36\end{array}$ & $\begin{array}{l}88 \\
72 \\
80 \\
46 \\
68 \\
62 \\
48 \\
42 \\
33 \\
18\end{array}$ & $\begin{array}{l}1 \cdot 06 \\
1 \cdot 19 \\
1 \cdot 15 \\
1 \cdot 29 \\
1 \cdot 29 \\
1 \cdot 22 \\
1.92 \\
1.62 \\
1 \cdot 72 \\
2.0\end{array}$ \\
\hline \multicolumn{2}{|c|}{$\begin{array}{l}\text { Mean } \\
\text { Standard deviation } \\
\text { Mean (normals) } \\
t \text { test (against normals) } \\
\mathbf{P}\end{array}$} & $\begin{array}{c}24 \cdot 7 \\
12 \cdot 4 \\
61 \cdot 8 \\
4.92 \\
>0.001\end{array}$ & $\begin{array}{c}12 \cdot 6 \\
6 \cdot 11 \\
43 \cdot 4 \\
3.65 \\
>0.001\end{array}$ & $\begin{aligned} 2.04 \\
0.57 \\
1.76 \\
1.06 \\
>0.1\end{aligned}$ & $\begin{array}{l}56 \cdot 4 \\
20 \cdot 3 \\
82 \cdot 6 \\
3 \cdot 71 \\
>0.001\end{array}$ & $\begin{array}{l}32 \cdot 9 \\
17 \cdot 7 \\
70 \cdot 1 \\
4 \cdot 33 \\
>0 \cdot 001\end{array}$ & $\begin{array}{c}1 \cdot 89 \\
0 \cdot 45 \\
1 \cdot 29 \\
4 \cdot 18 \\
>0 \cdot 001\end{array}$ & $\begin{array}{c}74.8 \\
19 \cdot 3 \\
89.4 \\
2.45 \\
>0.05\end{array}$ & $\begin{array}{l}55 \cdot 7 \\
22 \cdot 0 \\
84 \cdot 3 \\
3 \cdot 70 \\
>0 \cdot 001\end{array}$ & $\begin{aligned} 1.45 \\
0.34 \\
1.09 \\
3.57 \\
>0.002\end{aligned}$ \\
\hline
\end{tabular}

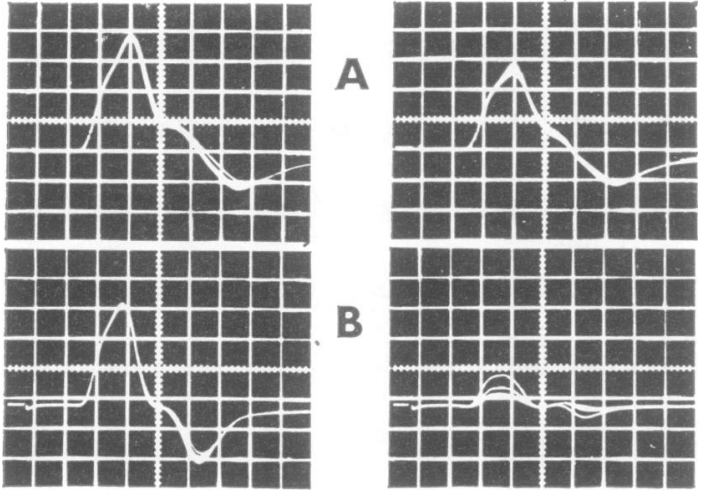

FIG. 6. Example of difference in curare-sensitivity between the affected and unaffected side in hemiplegia (patient H.R.). Superimposed MAP responses evoked by the stimulus trains. On the left before injection. On the right one minute after the release of the tourniquet after the injection of $0.5 \mathrm{mg}$ d-tubocurarine. A: Affected side. B: Unaffected side. $2 \mathrm{mV}$ per vertical division. 2 ms per horizontal division.

nearly complete at 21 minutes, in muscular dystrophy the responses are not significantly different from those at one minute and the fade during stimulus trains has not lessened.

In two patients, after 20 minutes of the study, edrophonium (Tensilon) $10 \mathrm{mg}$ was injected intravenously over two minutes into the contra lateral arm. Figure 1 shows that this appeared to facilitate recovery of the MAP only slightly, th 8 fade during stimulus trains persisting. In on patient stimulus trains at one minute intervals were delivered during the period of ischaemis and for the first five minutes after release of the $\overrightarrow{\bar{\theta}} \overrightarrow{0}$ tourniquet (Fig. 2). This shows that the max of mum effect has been achieved by one minute after the tourniquet release, a result comparable with normal subjects.

In patients with dystrophia myotonica the responses are not significantly different from the normal controls (Table 2, Fig. 3); while fairly $\bar{z}$ marked sensitivity is seen in some of these patients, in all instances the results are within the normal range. The number of subjects studied with myotonia congenita is not great enough for statistical analysis but the results are similar to those seen in normal subjects.

In patients with lower motor neurone lesions from various causes, the results are on the whole similar to those of normal controls (Table 3, Fig. 4), though a few do show fairly marked sensitivity.

The hemiplegic limb is less sensitive to curare than the unaffected limb (Table 4, Figs 5 and 6). $\%$ The initial depression of MAP was less marked $\tilde{O}$ $(t=2 \cdot 38, \mathrm{P}<0.05)$ and the degree of fade during $\mathrm{N}_{\mathrm{w}}$ 


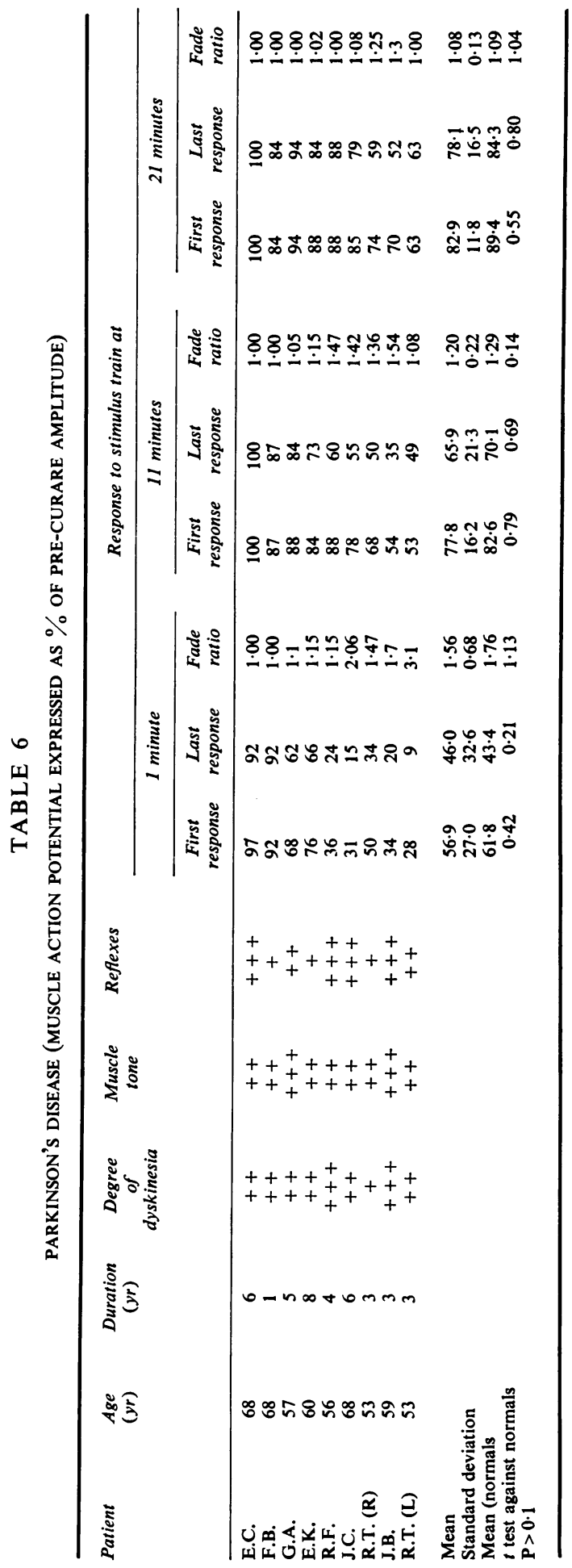




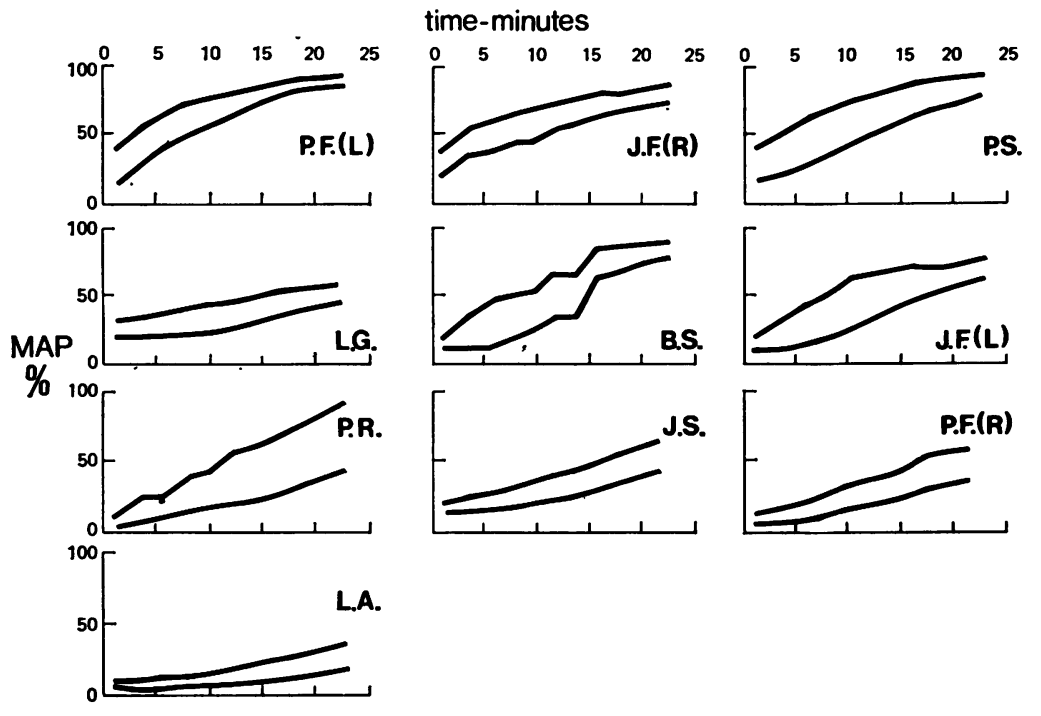

FIG. 7. ' Effect of 'regional' injection of $0.5 \mathrm{mg}$ d-tubocurarine in states of hyperreflexia (see text).

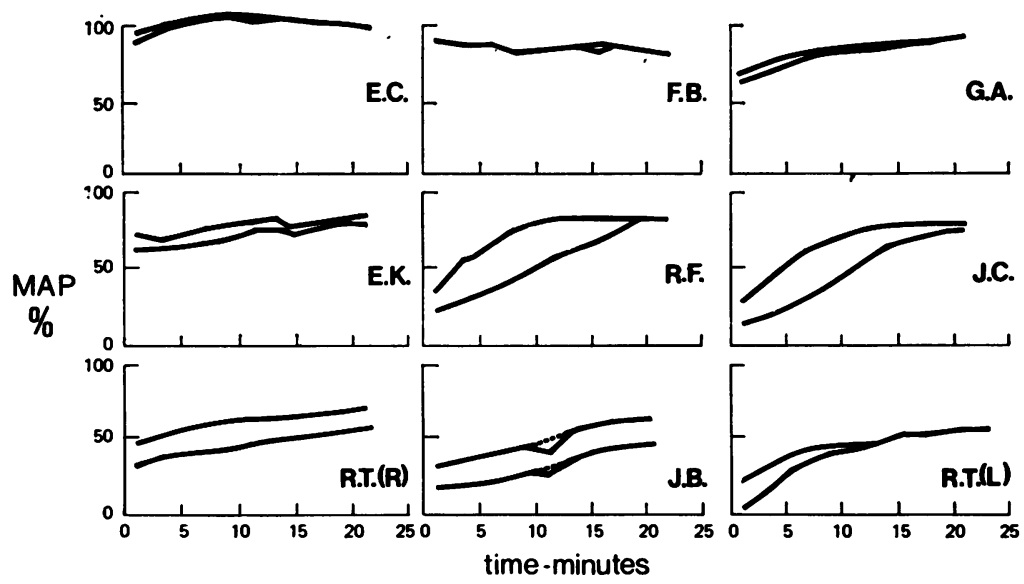

FIG. 8. Effect of 'regiona injection of $d$-tubocurarine $\overline{\overline{0}} \vec{\theta}$

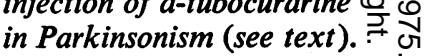

the stimulus train was less $(t=3.07, \mathrm{P}<0.01)$. Patient J.W., who had suffered a right and left hemiplegia at different times was insensitive on each side. Sensitivity did not correlate with the degree of weakness or its duration.

In contrast with the response in hemiplegia, patients with hyper-reflexia and hypertonia unaccompanied by weakness were more sensitive to curare than normal controls (Table 5 and Fig. $7)$, both initially $(t=4.92, \mathrm{P}<0.001)$ and after 21 minutes when the degree of fade was significantly greater $(t=3 \cdot 57, \mathrm{P}<0.002)$.

In Parkinsonism (Fig. 8) the range of response to curare in different subjects was wide. No significant difference was seen between such patients and normal subjects (Table 6, P>0.1).

\section{DISCUSSION}

While the response to d-tubocurarine in myotonic and lower motor neurone disorders re- $\rightarrow$ sembles that of normal subjects, a clear difference has emerged in Duchenne type muscular $N$ dystrophy. This response varies from normal in that the neuromuscular transmission block persists. This new observation on the duration of 
the block may have escaped detection when these patients have undergone anaesthesia, for such weakness may be attributed to the muscular dystrophy itself. It is likely to have clinical relevance, in that postoperative 'recurarization' may occur after the effect of the short-acting anticholinesterase wears off.

Could this response be the result of structural changes in the wasted hand, altering the diffusion of d-tubocurarine from the neuromuscular junction after the circulation is restored by release of the tourniquet? This seems unlikely: in the first place, this persisting neuromuscular transmission block seen in muscular dystrophy did not occur in equally weak and wasted muscles when this was a result of a variety of lower motor neurone disorders. Secondly, radioactive clearance studies using the methods described in normal subjects were similar in the normal and dystrophic hand. Finally, the d-tubocurarine takes no longer to exert its action at the neuromuscular junction than it does in normal subjects (Fig. 2).

Alterations in the property of the receptor site might be responsible for persisting binding of the curare, yet were this alone responsible for the duration of the block, at least some improvement would be anticipated when the tourniquet is released to lower suddenly the concentration of curare at the neuromuscular junction. That this does not occur in muscular dystrophy suggests that other factors should be considered.

Could a deficiency of acetylcholine effect competing at the receptor sites be the reason for the delayed recovery time in dystrophy? Only in myasthenic disorders have we found persistence of d-tubocurarine effects similar to that in Duchenne type muscular dystrophy (Brown and Charlton, 1975). The most striking curare sensitivity has been observed where there is a prejunctional defect in the acetylcholine release mechanism. The inability to overcome the curare-induced neuromuscular transmission block in muscular dystrophy could be explained similarly by a latent prejunctional disturbance, reducing the spontaneous release of acetylcholine between active neuromuscular transmissions. This suggestion would be in keeping with the view that in muscular dystrophy the pathological changes in the muscle fibre are a consequence of disordered function in the motor unit (McComas et al., 1971; Gallup and Dubowitz, 1973; Dastur and Razzak, 1973). In mouse muscular dystrophy there is a reduction in the number of synaptic vescicles before any change can be found in the muscle fibre (Ragab, 1971). An abnormality of this nature in established muscular dystrophy might well explain their prolonged curare sensitivity. Miledi and Slater (1970) have shown in mammalian studies that the neuromuscular junction is dependent upon trophic influences reaching it from the motor neurone. Hence, the finding of altered neuromuscular transmission in muscular dystrophy would be compatible with the disorder being the result of a prejunctional disturbance.

The possibility that postjunctional changes are responsible for the prolonged curare effect does however bear serious consideration. Altered capillary circulation is unlikely to be a significant factor since the mean muscle fibre area served per capillary is essentially normal in Duchenne type muscular dystrophy (Jerusalem et al., 1974a), but the recent demonstration of focal atrophy of the postsynaptic folds with decrease in postsynaptic relative to presynaptic length (Jerusalem et al., 1974b) might indicate that either the binding of curare is more persistent or that, in some other way, the altered postjunctional membrane affects the duration of the curare effect.

While decremental MAP responses may be obtained during neuromuscular stimulation in myotonic disorders (Ricker et al., 1973), the normal response to curare argues against there being any disorder of neuromuscular transmission. Although the area of the muscle fibre membrane sensitive to acetylcholine is increased after denervation and an altered response to depolarizing muscle relaxants may occur (Brim, 1973), from our limited study there is no consistent pattern of altered curare-sensitivity in cases of denervation.

The ability to withstand curare in the hemiplegic limb suggests that there is, in fact, a greater functional reserve than in normal subjects. It is of interest that in generalized myasthenia gravis the altered reactivity to acetylcholine and neostigmine may not be evident on the relevant side if the patient has also sustained a hemiplegia, and the occurrence of an upper motor neurone lesion may lead to the disappear- 
ance of clinical and electromyographic evidence of myasthenia (Grob et al., 1966). This 'improved' neuromuscular transmission is difficult to explain: could the weakness lead to the neuromuscular junction being 'rested'? This seems unlikely since, though the limbs were weak, most patients were still able to use the hand. Furthermore, this phenomenon has not been found in patients with other conditions that we have studied where there is definite muscular weakness due to lower motor neurone lesions.

Although the features of the next group of patients studied are also the result of upper motor neurone disturbance, they are clinically different. This group had significant hyperreflexia (and usually hypertonia) without weakness of arms or hands. Most were undergoing investigation of spastic paraplegia, the signs in the upper limbs being coincidental. They differ also from the group with hemiplegia in that their features were the result of a disorder in the spinal cord rather than the cerebral hemisphere. Whether neuromuscular transmission is affected by long-standing increase in muscle tone or by altered lower motor neurone activity as a result of the upper motor neurone disturbance is not yet clear.

No relationship has emerged between the duration of the hemiplegia and curare-sensitivity. The relative resistance to curare was evident in as little as three days or as much as five years after the stroke had occurred. This phenomenon cannot therefore be linked directly to the loss of motor units which occurs months after hemiplegia (McComas et al., 1973). At present we can only conclude that, when an upper motor neurone lesion rather than peripheral denervation causes weakness, relative insensitivity to curare occurs early and tends to persist. Either an increase in acetylcholine availability or an alteration in the property of the receptor site leading to a decrease in the curare binding could be responsible. Since the site of the initial disturbance is proximal, a prejunctional change, increasing spontaneous acetylcholine release is at least a possibility.

The effect of an upper motor neurone lesion upon neuromuscular transmission is clearly complex: where the weakness that accompanies a stroke predominates, there is an apparent resistance to the effects of curare on neuro- muscular function, whereas where hyper-reflexia and hypertonia predominate, there is an apparent sensitivity to the effects of curare on neuromuscular transmission. We suspect that, in most instances, there in an interplay between these two influences. Whether these alterations in curare sensitivity are the result of central or peripheral effects of the disease remains in doubt.

In the limited number of patients with Parkinsonism studied, the results resemble those of normal subjects. It is therefore unlikely that any marked consistent disturbance of neuromuscular transmission will be found in this disorder.

We wish to thank Mr P. Smith for technical assistance, Miss M. Stevenson for secretarial assistance, and Mr E. Stanley for help with statistical analysis. We are grateful to Dr F. R. Ellis and Dr D. J. Aidley for helpful advice and to Dr J. Anderson, Dr W. G. Bradley, Dr R. A. L. Brewis, Dr H. A. Dewar, ando Dr D. A. Shaw for permission to study their patientso This work was supported by Grant 17912 from the Medical Research Council.

\section{REFERENCES}

Baginsky, R. G. (1968). A case of peripheral polyneuropathx displaying myasthenic EMG patterns. (Abstract.) Electro encephalography and Clinical Neurophysiology, 25, 397.

Brim, V. D. (1974). Denervation supersensitivity: the response to depolarizing muscle relaxants. British Journal of Anaesthesia, 45, 222-226.

Brown, J. C., Charlton, J. E., and White, D. J. K. (1975). A regional technique for the study of sensitivity to curare in human muscle. Journal of Neurology, Neurosurgery, and Psychiatry, 38, 18-26.

Brown, J. C.; and Charlton, J. E. (1975). A study of sensitivity to curare in myasthenic disorders using a regional technique. Journal of Neurology, Neurosurgery, and Psychiatry, 38, 27-33.

Dastur, D. K., and Razzak, Z. A. (1973). Possible neurogenic factor in muscular dystrophy: its similarity to denervation atrophy. Journal of Neurology, Neurosurgery, and Psychiatry, 36, 399-410.

Gallup, B., and Dubowitz, V. (1973). Failure of 'dystrophic' neurones to support functional regeneration of normal or dystrophic muscle in culture. Nature, 243, 287-289.

Grob, D., Namba, T., and Feldman, D. S. (1966). Alterations in reactivity to acetylcholine in myasthenia gravis and carcinomatous myopathy. Annals of the New York Academy of Sciences, 135, 247-275.

Isch-Treussard, C., Jesel, M., and Isch, F. (1968). EMG study of two cases of von Eulenburg's congenital paramyotonia. (Abstract.) Electroencephalography and Clinical Neurophysiology, 25, 405.

Jerusalem, F., Engel, A. G., and Gomez, M. R. (1974a). Duchenne dystrophy. 1. Morphometric study of the muscle microvasculature. Brain, 97, 115-122. 
Jerusalem, F., Engel, A. G., and Gomez, M. R. (1974b). Duchenne dystrophy. 2. Morphometric study of motor end-plate fine structure. Brain, 97, 123-130.

McComas, A. J., Sica, R. E. P., and Currie, S. (1971). An electrophysiological study of Duchenne dystrophy. Journal of Neurology, Neurosurgery, and Psychiatry, 34, 461-468.

McComas, A. J., Sica, R. E. P., Upton, A. R. M., and Aguilera, N. (1973). Functional changes in motoneurones of hemiparetic patients. Journal of Neurology, Neurosurgery, and Psychiatry, 36, 183-193.

Mathew, N. T., Jacob, J. C., and Chandy, J. (1970). Familial ocular myopathy with curare sensitivity. Archives of Neurology, 22, 68-74.

Miledi, R., and Slater, C. R. (1970). On the degeneration of rat neuromuscular junctions after nerve section. Journal of Physiology, 207, 507-528.

Mulder, D. W., Lambert, E. H., and Eaton, L. M. (1959). Myasthenic syndrome in patients with amyotrophic lateral sclerosis. Neurology (Minneap.), 9, 627-631.

Oosterhuis, H. J. G. H., and Haas, W. H. D. de (1969). Curare sensitivity and myastheniform symptoms in patients with rheumatoid arthritis. Acta Rheumatologia Scandinavica, 15, 54-61.

Ragab, A. H. M. F. (1971). Motor-end-plate changes in mouse muscular dystrophy. Lancet, 2, 815-816.
Ricker, K., and Mertens, H. G. (1968). Myasthenic reaction in primary muscle fibre disease. Electroencephalography and Clinical Neurophysiology, 25, 413-414.

Ricker, K., Meinck, H.-M., and Stumpf, H. (1973). Neurophysiologische Untersuchungen über das Stadium passagerer Lähmung bei Myotonia congenita und Dystrophia myotonica. Zeitschrift für Neurologie, 204, 135-148.

Ross, R. T. (1963). Ocular myopathy sensitive to curare. Brain, 86, 67-74.

Sica, R. E. P., Herskovits, E., Aguilera, N., and Poch, G. (1973). An electrophysiological investigation of skeletal muscle in Parkinson's disease. Journal of Neurological Sciences, 18, 411-420.

Simpson, J. A. (1974). Myasthenia gravis and myasthenic syndromes. In Disorders of Voluntary Muscle, pp. 653-692, 3rd edn. Edited by J. N. Walton. Churchill Livingstone: Edinburgh.

Tuncbay, T. O., and Boshes, B. (1966). Studies in muscle and motor end plate enzymes. 1. Neuromuscular disorders. Annals of the New York Academy of Sciences, 135, 98-109.

Young, I. J. (1966). Morphological and histochemical studies of partially and totally deafferented spinal cord segments. Experimental Neurology, 14, 238-248. 